This item was submitted to Loughborough's Research Repository by the author.

Items in Figshare are protected by copyright, with all rights reserved, unless otherwise indicated.

\title{
Irish droughts in newspaper archives: rediscovering forgotten hazards?
}

\section{PLEASE CITE THE PUBLISHED VERSION}

https://dx.doi.org/10.1002/wea.2904

\section{PUBLISHER}

(c) Royal Meteorological Society. Published by Wiley

\section{VERSION}

AM (Accepted Manuscript)

\section{PUBLISHER STATEMENT}

This work is made available according to the conditions of the Creative Commons Attribution-NonCommercialNoDerivatives 4.0 International (CC BY-NC-ND 4.0) licence. Full details of this licence are available at: https://creativecommons.org/licenses/by-nc-nd/4.0/

\section{LICENCE}

CC BY-NC-ND 4.0

\section{REPOSITORY RECORD}

Murphy, Conor, Simon Noone, Catriona Duffy, Ciaran Broderick, Tom Matthews, and Robert Wilby. 2019. "Irish Droughts in Newspaper Archives: Rediscovering Forgotten Hazards?". figshare.

https://hdl.handle.net/2134/23305. 


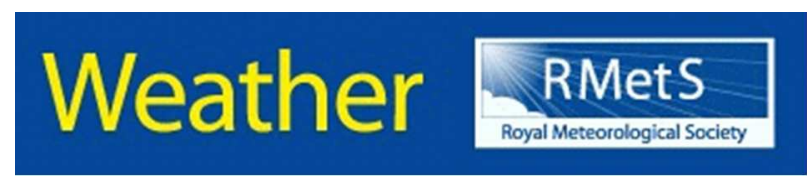

\section{Irish droughts in newspaper archives: Rediscovering forgotten hazards?}

\begin{tabular}{|r|l|}
\hline Journal: & Weather \\
\hline Manuscript ID & WEA-16-0055.R2 \\
\hline Wiley - Manuscript type: & Research Article \\
\hline Date Submitted by the Author: & $14-$ Sep-2016 \\
\hline Complete List of Authors: & $\begin{array}{l}\text { Murphy, Conor; National University of Ireland Maynooth, Irish Climate } \\
\text { Analysis and Research Units, Department of Geography } \\
\text { Noone, Simon; National University of Ireland Maynooth, Irish Climate } \\
\text { Analysis and Research Units, Department of Geography } \\
\text { Duffy, Catriona; National University of Ireland Maynooth, Irish Climate } \\
\text { Analysis and Research Units, Department of Geography } \\
\text { Broderick, Ciaran; National University of Ireland Maynooth, Irish Climate } \\
\text { Analysis and Research Units, Department of Geography } \\
\text { Matthews, Tom; Liverpool John Moores University, School of Natural } \\
\text { Sciences and Psychology, } \\
\text { Wilby, Robert; Loughborough University, Geography }\end{array}$ \\
\hline Keywords: & Drought, Newspaper Archives, Ireland, Geo-engineering, Religion, Water \\
\hline \multicolumn{2}{|c}{} \\
\hline \multicolumn{2}{|c}{} \\
\hline
\end{tabular}




\title{
Irish droughts in newspaper archives: Rediscovering forgotten hazards?
}

Conor Murphy ${ }^{1}$, Simon Noone ${ }^{1}$, Catriona Duffy ${ }^{1}$, Ciaran Broderick ${ }^{1}$, Tom Matthews ${ }^{2}$ and Robert L. Wilby ${ }^{3}$.

${ }^{1}$ Irish Climate Analysis and Research UnitS (ICARUS), Department of Geography, Maynooth University, Kildare, Ireland.

${ }^{2}$ School of Natural Sciences and Psychology, Liverpool John Moores University, Liverpool L3 $3 A F$, England, $U K$.

${ }^{3}$ Department of Geography, Loughborough University, Loughborough LE11 3TU, England, $U K$

Corresponding Author: Conor Murphy (email: conor.murphy@nuim.ie; tel:+353 1 7083494)

Running Head: Irish droughts in newspaper archives

\begin{abstract}
Irish newspaper collections are a rich source of information on historical droughts. Following a search of 250 years of such archives, this paper brings to light four newspaper articles describing three drought events that convey the cultural impacts and unusual societal responses to nineteenth century drought in Ireland. Amongst the archives we find two poems from 1806 and 1893, a call to pray for rain in 1887 , and a suggestion for weather modification in 1893 . These records demonstrate that, contrary to recent experience, Ireland is surprisingly prone to drought.
\end{abstract}

\section{Keywords: Drought, Newspaper Archives, Ireland, Geo-engineering, Religion, Water}




\section{Introduction}

"Irish drought" might appear to be an oxymoron. However, the Island of Ireland has been surprisingly drought prone over the last couple of centuries, but perhaps less so in living memory. We recently established a 160-year drought catalogue for the island covering the period 1850-2015 (Noone et al., 2015; Wilby et al., 2015). This was subsequently extended by Noone et al. (2016) to create a 250 year drought catalogue for Ireland (1765-2015) based on the Standardised Precipitation Index (SPI). In constructing this extended drought catalogue we used documentary sources from newspaper archives spanning the last 250 years. Together with other historical sources, these add confidence to the quantitative detection of drought episodes from rainfall records and provide glimpses into the socio-economic impacts of historic droughts.

As we discovered, Ireland is in the fortunate position of having some of the longest running newspapers in the world. Of particular note are the Belfast Newsletter (one of the world's oldest continuously published newspaper) and the Freeman's Journal which began reporting in the early and mid 18th Century respectively. Another nine titles commenced in the 19th Century, with many continuing to the present day (see Table 1). Noone et al. (2016) show that newspaper archives can be used to trace the progression of drought events and impacts. Articles reveal that over the last 250 years droughts have resulted in agricultural hardship, water resource crises and failures, and preceded some of the major famines of the 18th and 19th centuries. They also show that Ireland was subject to persistent multi-season drought episodes in the $1800 \mathrm{~s}, 1820 \mathrm{~s}, 1850 \mathrm{~s}$, $1880 \mathrm{~s}$, and in the twentieth century in the 1920s, 1930s, 1950s and 1970s.

During our trawl of the newspaper archives we uncovered hundreds of articles referring to drought in all its guises. In this paper, we bring to life four notable articles that convey aspects of three significant droughts in the 19th Century. These articles are selected as they relay the cultural influence of drought and some unusual societal responses that reflect the historical context. The following sections introduce each article and provide a short narrative of the drought event in which they appeared. For interested readers, full details of the specific droughts mentioned and their quantitative assessment are given by Noone et al. (2016). We close with some reflections on how such events might (re)shape modern perceptions of drought and how newspaper archives might be further exploited in understanding historic weather extremes. 


\section{'Drought' 1806}

The period September 1800 to January 1809 was one of the most persistent drought episodes in the island of Ireland of the past 250 years. In fact, this period was marked by three individual drought events, separated only by brief wet interludes of three months or less (Noone et al., 2016). There is evidence from newspaper records that, at least early in the event, drought impacts were not island wide with counties Leitrim and Roscommon supplying potatoes and other crops for severely impacted areas in the south and west (FJ,03.01.1801 page 2). Reports in the Freeman's Journal highlight that the woollen industry declined in 1802 due to a lack of water to work the mills (FJ,09.09.1800 page 3). The 1851 Census of Ireland refers to the years 1800, 1801 and 1803 as being excessively hot and dry. During 1802 officials put in place financial support so that grain and maize could be imported from the United States to help alleviate the emergency with disease and death also prevalent during this period (Ó Gráda, 2015). At this time, there are also several reports of widespread potato crop failure, the staple food source, causing severe hardship for the population (FJ,15.07.1806, page 2).

On the 8 July 1806 a poem simply entitled 'Drought' appeared in the Belfast Newsletter. The poem, signed HAFIZ, was written on the 28 June 1806 and is reproduced in Figure 1. It provides a powerful depiction of the devastating impact of drought, with the tone and language pleading for reprieve from the "demon" drought. The poem begins with reference to the emergence of drought in spring, noting impacts on local water bodies in the second verse, impacts on agriculture and flora in the third, and devastation of the water-powered linen industry in the fourth verse. The last two verses long for wet conditions and the return of rain, making reference to both Greek mythology and astronomy. In Greek mythology, the 'Pleiads' refer to the seven daughters of Atlas and Pleoine. In astronomy, the Pleiads or seven sisters are stars in the constellation Taurus; primarily winter stars, featuring prominently in the ancient agricultural calendar, along with Orion. Hence, the plea for them both to rise is a call for the end of summer and the arrival of rain. Reference to the 'Naiads' is again an appeal to the female spirit of fresh water bodies in Greek mythology.

\section{'Pray for Rain' 1887}


The drought of 1887 was one of the most intense, island-wide droughts experienced in the last 250 years (Noone et al., 2016). The event itself is well documented by Richard M. Barrington (1888) who mapped the spatial extent of rainfall anomalies over the previous five years and provided detailed insight to the agricultural impacts. This drought commenced in early spring of 1887 and continued well into autumn. Figure 2 shows an image of the original 1887 daily reporting sheet taken at Fassaroe, Bray, Co. Wilckow, by Richard M. Barrington. Evident is the occurrence of just 9 rain days in February and April and only 4 rain days in June. Overall Barrington (1888) reports that 10 months in 1887 saw deficient rainfall relative to the previous 30 year monthly means. By summer 1887, with the long drought threatening to become a national calamity, the Bishop of Meath issued a circular entitled 'The Drought'. This appeared in the Irish Times on July 21887 and called the faithful to pray for rain. Figure 3 provides a transcript of the original article and is a sign of the desperation that must have been felt across society. Figure 4 shows a classic high pressure blocking system present over Ireland on June 30 1887 which was typical of much of that month. Also shown in Figure 4 is the weather chart for July 2, the day the call to prayer appeared in print. Noone et al. (2016) establish that this drought was the most intense in the east of the country and led to widespread crop failures and water supply issues. In the city of Dublin, the state of the public sewers gave rise to public health concerns due to a lack of water to flush the system (Noone et al., 2016). The prayers were answered in November 1887 when the drought broke. As far as we can tell, this is the only public call for drought-relief by prayer in the 250 years of the Irish newspaper archive [although such cries continue to be heard in other places and cultural contexts today ${ }^{1}$ ].

\section{Dublin Water Crisis 1893}

In spring 1893, an extreme drought began that eventually severely affected the east and southeast of Ireland, culminating in a water supply crisis for Dublin City by autumn. The Freeman's Journal states on the 27 April 1893 that "there has been an absolute drought since March 5th - for fifty two days". The article then quotes Mr. Symons, the eminent English Meteorologist, who said that "this is by far the longest period during which dry conditions have prevailed" since he began making observations in 1857 (FJ, 27.04.1893, page 8).

\footnotetext{
${ }^{1}$ See for example, prayers to end the California drought: http://ismreview.yale.edu/article/praying-for-rain-in-thecalifornia-drought/
} 
By September 1893, the Freeman's Journal reported that "the great drought of the present season has reduced the water supply of the city to such an extent that the greatest care and economy will be required on the part of the citizens to avert the calamity of a water famine" (FJ, 05.09.1893, page 4). Water usage in the city was reduced from 15 to 10 million gallons per day by imposing water restrictions during September. By October the City could only rely on 16 days of supply from the Vartry. For long periods, northern parts of Dublin City were reduced to intermittent supplies delivered between $10 \mathrm{pm}$ and $10 \mathrm{am}$ at the request of local bakeries (IT, 31.10.1893, page 5). In addition to water supply issues, residents spoke of the foul smell from city sewers and fear of disease due to a lack of water to flush the waste (IT, 30.06.1887, page 6; IT, 21.07.1887, page 5).

At that time, Dublin's main source of potable water was from a reservoir on the River Vartry at Roundwood, County Wicklow. This reservoir still contributes to Dublin's water supply today. At capacity in 1893, the reservoir provided four months of water supply for the city (Walker, 1894). The crisis of supply caused debate within the media and academic circles about the primary cause of failure and potential solutions. In March 1894, John A. Walker, chairman of the Dublin Waterworks committee, gave a paper to the Statistical and Social Inquiry Society of Ireland entitled 'Our Present and Future Water Supply'. In it he argued that the drought was exacerbated by an expansion of the urban area supplied by the Vartry reservoir, beyond the initial design assumptions, to suburban areas of the city where wastage among wealthy households was seen as profligate (Walker, 1894). This view was supported by others in the audience as recounted the following day (IT, 14.03.1894, page 7).

By November 1893, The Irish Times was documenting meetings of the Waterworks Committee who were making arrangements to secure additional supplies from the Royal Canal to meet Dublin's water needs (IT, 01.11.1893, page 5). The newspaper also reported no change in conditions at the Vartry reservoir later in the same month, with a Waterworks Committee meeting held at City Hall to consider plans and cost estimates for the damming of Lough Dan in the Wicklow Mountains (IT, 15.11.1893, page 5). Other options considered included the transfer of water from the River Ovoca (Avoca) and its tributaries by tunnelling through the watershed between Lough Tay and Lough Dan (IT, 28.11.1893, page 5). Ultimately, plans to dam Lough Dan were deemed too expensive and never came to fruition. 
On 30 December 1893, at the end of the drought, a poem entitled 'Water' (Figure 5) appeared in the Irish Times. The poem, signed W. I. R., satirized the events of the drought, the surrounding controversies and courted solutions. Against the tapping of Loch Dan, the author proceeds to put forward a plan 'to make the Vartry do'. It calls for seasonal metering of water consumption and fines for wasteful use. The finger is pointed at housewives, in reference to the blame assigned to suburban locations for their reckless water usage. Scorn is also poured on the use of filtered Vartry waters to 'sprinkle on the streets' and fill tankers, presumably for fire fighting. The poem points out that for these purposes, sea water or untreated water from other streams would have sufficed.

The drought and subsequent water supply crisis in 1893 obviously left a major impression on the public imagination. Facing intermittent supplies and water restrictions, one member of the public wrote to the Irish Times on the 16 September 1893 about 'The Protracted Drought' and made an audacious suggestion. In the letter, the author (signed A. Citizen) recommends a weather modification experiment to bring an end to the drought by exploding dynamite above the city to urge the obvious clouds to give up their moisture (Figure 6). As the author claims, this experiment would indeed have proved novel, if in the end unlikely to alter the course of events. Even so, the proposal is not so far removed from modern-day cloud-seeding and controversial geoengineering technologies. Figure 4 depicts the pressure conditions in situ when the article appeared in print.

\section{Conclusions}

Recollections of past extremes can play a role in building resilience to future events (McEwen and Jones, 2012). Recent decades have been conspicuously drought free in Ireland (Wilby et al., 2015; Noone et al., 2016), to the extent that most recent experiences of protracted drought are based on the mid-1970s. Although short, sharp droughts occurred in the summers of 1995, 2006 and 2013 these events bear little resemblance to the long and intense droughts of earlier centuries, often spanning multiple seasons and even years. This raises questions about whether the underlying causes of long droughts in Ireland have changed in the interim. Moreover, past events challenge water managers to consider how they might manage a repeat episode of 1887 or 1893, given the present supply-demand balance in Dublin, and the condition of 
infrastructure (much of which is the same as in the 19th Century). Information on historic droughts uncovered by this research is currently feeding into water resource and drought planning in Ireland.

The paucity of notable recent droughts also highlights the value of recalling past events from media archives. Newspapers provide an important source of such information, particularly where confidence in observations decreases, which is the case in Ireland prior to 1850. Noone et al. (2016) show that newspaper archives can be cross-referenced with available observations, other documentary sources and indeed other drought catalogues (e.g. Marsh et al., 2007). As we show here, Ireland is fortunate to have rich archives that contain interesting eye-witness accounts of how drought can impact society. As evident for the 1893 event, newspaper archives even help to add detail to how the drought impacts propagated through society. In addition, the 1851 Census of Ireland contains valuable information on various weather extremes prior to 1850. An interesting avenue for further research would be to investigate how these sources corroborate each other for overlapping periods. A further important avenue is to continue efforts to digitise archived data to extend both the temporal and spatial understanding of historic droughts while there are other documentary sources such as weather diaries (e.g. Dixon, 1959) that can help extend assessments of drought further back in time. Finally, it is our hope that this paper will serve to remind that Ireland is, despite popular perceptions and recent experience, surprisingly drought prone.

\section{Acknowledgements}

Simon Noone was funded by the Irish Research Council. Conor Murphy, Ciaran Borderick and Catriona Duffy acknowledge funding provided by Environmental Protection Agency grant no. 2014-CCRP-MS.16.

\section{References}


Barrington, R. M. 1888. The drought of 1887, and some of its effects on Irish agriculture. J. Stat. Soc. Inquiry Soc. Ireland, Vol. IX Part LXVII, 223-247.

Dixon, F.E. 1959. An Irish weather diary of 1711-1725. Q.J.R. Meteorol. Soc. 85 (366), 371-385.

Marsh, T., Cole, G. and Wilby, R.L. 2007. Major droughts in England and Wales, 1800-2006. Weather, 62, 87-93.

McEwen, L. and Jones, O. 2012. Building local/lay flood knowledges into community flood reslience planning after the July 2007 floods, Gloucestershire, UK. Hydrol. Res., 43 (5), 675688.

Noone, S., Murphy, C., Coll, J., et al. 2015. Homogenisation and analysis of an expanded monthly rainfall network for the Island of Ireland (1850-2010). International Journal of Climatology, doi:10.1002/joc.4522.

Noone, S., Broderick, C., Duffy, C., et al. 2016. A 250 year drought catalogue for the Island of Ireland (1765-2015). Int. J. Climatol.. Submitted.

Ó Gráda C. 2015. Famine in Ireland, 1300-1900. UCD Centre For Economic Research Working Paper Series 2015, University College Dublin, Belfield Dublin 4.

Walker, J.A. 1894. Our Present and Future Water Supply. J. Stat. Soc. Inquiry Soc. Ireland, Vol. X Part LXXIV, pp22-34.

Wilby R. L., Noone, S., Murphy, C., et al. 2015. An evaluation of persistent meteorological drought using a homogeneous Island of Ireland precipitation network. International Journal of Climatology, doi:10.1002/joc.4523. 


\section{Figure Captions}

Figure 1 The poem 'Drought' which appeared in the Belfast Newsletter on the 28 June 1806.

Figure 2 Image of the daily rainfall sheet for 1887 at Fassaroe, Bray, Co. Wicklow. The gauge was maintained by Richard M. Barrington and we thank the Met Éireann Library for access to the archives for this station.

Figure 3 Circular from the Bishop of Meath authorising the prayer for rain. Published in the Irish Times on 2 July 1887.

Figure 4 Weather charts for i) June 301887 (left) showing classical high pressure blocking that dominated that month when only 4 rain days occurred at Fassaroe, Bray on the east coast of Ireland (see Figure 2); ii) July 21887 when the circular issuing a call to pray for rain appeared in the Irish Times (see Figure 4) and; iii) 16 September 1893 when the weather modification letter appeared in the Irish Times (see Figure 6).

Source: UK Met Office Daily Weather Reports.

Figure 5 The poem 'Water' that appeared in The Weekly Irish Times on 30 December 1893. Italicised words identify those we had trouble transcribing due to blurring of the original.

Figure 6 Letter to the Irish Times published 16 September 1893 proposing exploding dynamite over Dublin to induce rainfall. 
Table 1 Newspaper titles accessed through the Irish Newspaper Archive (www.irishnewsarchive.com) together with the abbreviations used in text, the start and end dates of publication, readership (national/county) and frequency of publication.

\begin{tabular}{lclll}
\hline Title & Abbreviation & Start and end year & County & $\begin{array}{l}\text { Publication } \\
\text { Frequency }\end{array}$ \\
\hline Belfast Newsletter & BN & $09 / 01 / 1738-30 / 08 / 1890$ & National (NI) & Daily \\
Freeman's Journal & FJ & $03 / 01 / 1763-19 / 12 / 1924$ & National & Daily \\
Kerry Evening Post & KEP & $1813-1917$ & Kerry & Weekly \\
Tuam Herald & TH & $13 / 05 / 1837-$ Current & Galway & Weekly \\
Nenagh Tribune & NT & $21 / 07 / 1838-$ Current & Tipperary & Weekly \\
Irish Examiner & IE & $30 / 08 / 1841-1999$ & National & Daily \\
The Nation & N & $15 / 10 / 1842-05 / 06 / 1897$ & Dublin & Weekly \\
Tralee Chronicle & TC & $18 / 03 / 1843-20 / 05 / 1881$ & Kerry & Daily \\
Anglo-Celt & AC & $06 / 02 / 1846-$ Current & Cavan & Weekly \\
Western People & WP & $04 / 05 / 1889-$ Current & Mayo & Weekly \\
Meath Chronicle & MC & $01 / 05 / 1897-$ Current & Meath & Weekly \\
Longford Leader & LL & $14 / 08 / 1897-$ Current & Longford & Weekly \\
Kerryman & K & $20 / 08 / 1904-$ Current & Kerry & Weekly \\
Irish Independent & II & $02 / 01 / 1905-$ Current & National & Daily \\
Connacht Tribune & CT & $22 / 05 / 1909-$ Current & Galway & Weekly \\
Irish Press & IP & $05 / 09 / 1931-25 / 05 / 1995$ & National & Daily \\
Irish Framers Journal & IFL & $16 / 03 / 1957-26 / 12 / 1998$ & National & Weekly \\
Irish Times & IT & $1785-$ Current & National & Weekly \\
Nenagh Guardian & NG & $21 / 07 / 1838-$ Current & Sligo & Weekly \\
Leinster Express & LE & $24 / 09 / 1831-$ Current & Offaly & Weekly \\
\hline
\end{tabular}




\section{Belfast Newsletter, July $8^{\text {th }} 1806$, page 4}

\section{DROUGHT}

SEE ! the demon Drought appears, Wide he waves his fiery wing, Drinking up night's dewy tears, Preying on the bloom of spring.

Bending o'er their wasted urns, Hark ! the sedge-crown'd sisters weep; Banna sighs, and Lagan mourns, As they travel to the deep.

Agriculture droops his head, As the with'ring pow'r he eyes : Flora's heart is fill'd with dread, While with thirst her offspring dies.

Idle sad Linlea views

All her stream-turn'd engines stand, Where the bleachfields bright diffuse Wealth and beauty o'er the land.

Rise, ye Pleiads pity take -

Bid the kindly rain descend -

Joyful the Naiads make Drooping Nature's tribes befriend.

Thou, Orion, too arise !

Wide thy glittering faulchoin wield -

Soon the tyrant of the skies

To thy magic pow'r shall yield

June 28, 1806

HAFIZ

Figure 1 The poem 'Drought' which appeared in the Belfast Newsletter on the 28 June 1806. Figure 1

$111 \times 195 \mathrm{~mm}(300 \times 300 \mathrm{DPI})$ 
$\sin 8 g^{20}$

REGISTER OF RAINFALL IN 188

Kept at Gassaroe

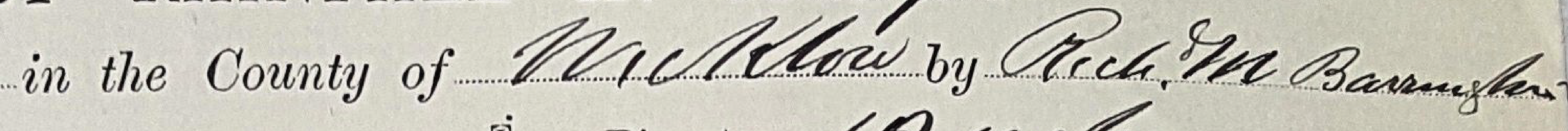
Latitude

Longitude

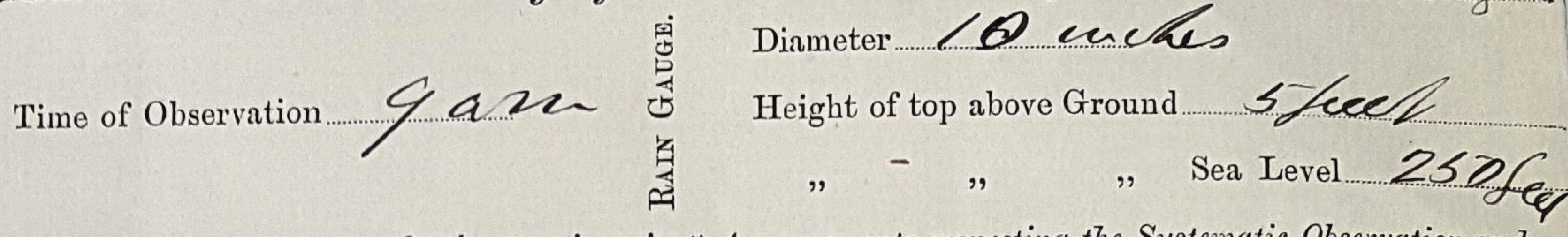

None.-Full instructions respecting the measurement of rain are given in "Arrangements respecting the Systematic Observation and Record of the Rainfall of the British Isles," which is sent post-free on application to Mr. G. J. Srmovs, 62, Camden Square, London, N.W.

\begin{tabular}{|c|c|c|c|c|c|c|c|c|c|c|c|c|c|}
\hline Date. & Jan. & Feb. & March. & April. & May. & June. & July. & Aug. & Sept. & Oct. & Nov. & Dec. & Date. \\
\hline 1 & in. & 150 & in. & in. & 060 & .055 & in. & in. & .800 & in. & .040 & in. & 1 \\
\hline 2 & .040 & .450 & & & & .030 & & & .190 & & .550 & & 2 \\
\hline 3 & 540 & 200 & & & & $.1 / 0$ & & & .090 & & .200 & .055 & 3 \\
\hline 4 & 340 & .020 & & 1100 & & & & & .150 & & .090 & & 4 \\
\hline 5 & .050 & & & 240 & & & & & , & & 1.080 & .500 & 5 \\
\hline 6 & $.0 \% 0$ & & & & & & & & $1 / 10$ & & .380 & .050 & 6 \\
\hline 7 & .110 & & & & & .090 & & & .040 & .040 & 260 & .150 & 7 \\
\hline 8 & & & & & .025 & & $.0 \% 0$ & & .020 & 430 & & .160 & 8 \\
\hline 9 & & & & & & & .150 & & .025 & .410 & .010 & .050 & 9 \\
\hline 10 & 1.380 & & & & & & & & .010 & .010 & .015 & $.020^{1}$ & 10 \\
\hline 11 & & & .560 & & .010 & & & & .080 & $.0 \% 5$ & -.085 & - & 11 \\
\hline 12 & & & .020 & & & & 260 & 1,100 & & & .020 & $.400^{1}$ & 12 \\
\hline 13 & & $.0 \% 5$ & -.035 & & & & 110 & .100 & & & .050 & $.055^{-1}$ & -13 \\
\hline 14 & .020 & .030 & 0.140 & & .020 & & .010 & & & & .840 & $.230^{1}$ & 14 \\
\hline 15 & & & .010 & & & & & & & & & $140^{1}$ & 15 \\
\hline 16 & $14+0$ & .040 & .060 & & & & & & & & & $.060^{1}$ & 16 \\
\hline 17 & .300 & & $.0 \% 0$ & & .025 & & & .320 & & & & $.1455^{1}$ & 17 \\
\hline 18 & .095 & & & & .020 & & & .040 & & & .015 & $080^{1}$ & 18 \\
\hline 19 & .185 & & .035 & & .480 & & & .100 & & & 320 & & 19 \\
\hline 20 & & & & & .120 & & & & & & $.025 t$ & $-1400=$ & 20 \\
\hline 21 & & & .320 & .100 & .130 & & & & & & .625 & & 21 \\
\hline 22 & & & .600 & .300 & 200 & & & & & & .320 & & 22 \\
\hline 23 & & .050 & $.0 \% 0$ & .160 & & & .010 & & & .285 & & & 23 \\
\hline 24 & .210 & .160 & .185 & .160 & & & .090 & .040 & & & & .010 & 24 \\
\hline 25 & .020 & & .145 & .190 & .010 & & & .100 & .040 & & & .025 & 2 \\
\hline 26 & & & .050 & .040 & & & .230 & .460 & & .365 & .200 & & 2 \\
\hline 27 & .015 & & .0157 & .220 & .060 & & & 1,520 & & & .080 & .010 & 2 \\
\hline 28 & & & & & & & & .130 & .090 & .025 & .330 & .220 & 2 \\
\hline 30 & .120 & & & & & & .020 & .140 & .060 & 150 & & & \\
\hline 31 & .310 & & .045 & & .300 & & 420 & .120 & & 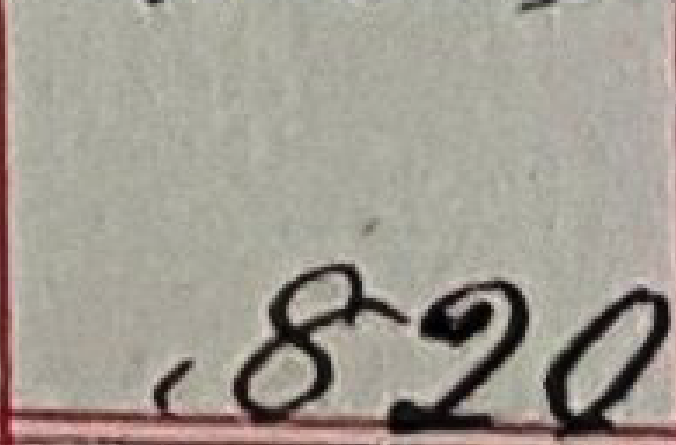 & & & \\
\hline Totals & 3.945 & 1.205 & 2,420 & 1.520 & 1.460 & 1285 & 1.480 & 4.230 & 1.495 & 2.640 & 4,565 & 42.530 & \\
\hline
\end{tabular}




\section{The Irish Times, July 2, 1887, page 5}

\section{The Drought}

The following circular has been issued by the Bishop of Meath:

Ballymacoll House, Dunboyne, July 1st 1887

"Rev. And Dear Brother, - The long drought threatens to become a national calamity. Agreeably to the apostolic precept, that in all things, by prayer and supplication, with thanksgiving, our requests should be declared to God, our Church sanctions public prayers for such changes of weather as may be most conducive to human comfort and prosperity.

'I therefore authorise you, under the present circumstances, to use the prayer for rain, nothing doubting that our Heavenly Father will graciously accept the humble petitions of His people, and will dispose of all things for the real welfare of those who approach Him in the spirit of trustful resignation to $\mathrm{His}$ will, - I am always your loving friend and bishop,

"C.P. Meath"

Figure 3 Circular from the Bishop of Meath authorising the prayer for rain. Published in the Irish Times on 2 July 1887.

Figure 3

$114 \times 166 \mathrm{~mm}(300 \times 300$ DPI) 

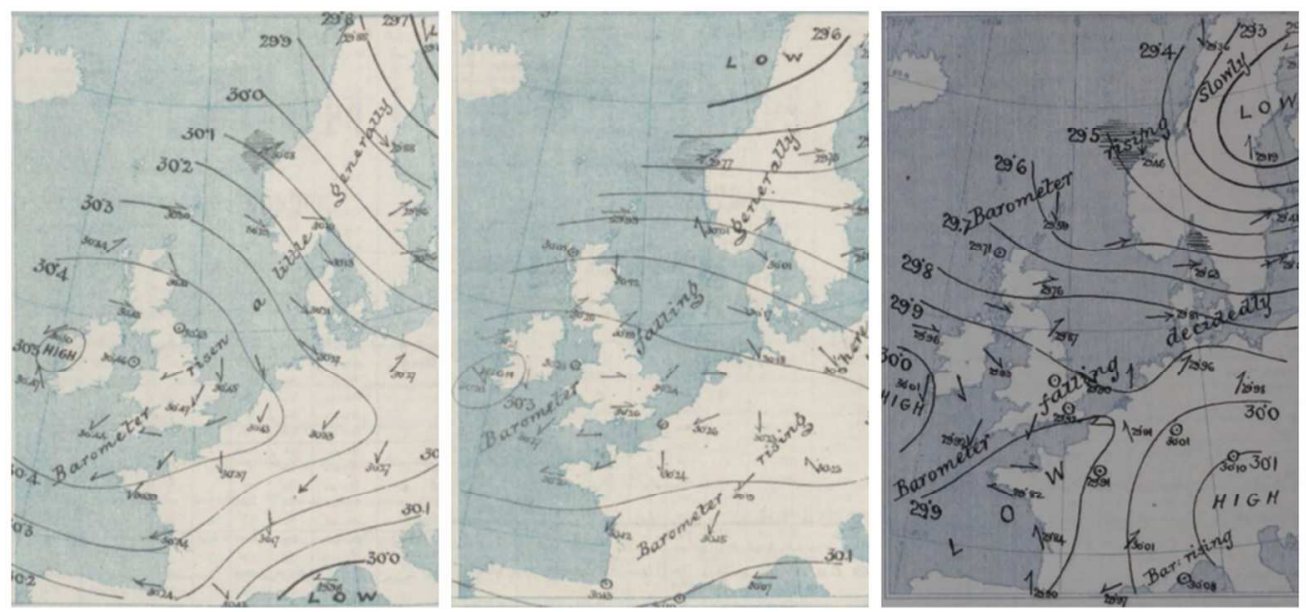

Figure 4 Weather charts for i) June 301887 (left) showing classical high pressure blocking that dominated that month when only 4 rain days occurred at Fassaroe, Bray on the east coast of Ireland (see Figure 2); ii) July 21887 when the circular issuing a call to pray for rain appeared in the Irish Times (see Figure 4) and; iii) 16 September 1893 when the weather modification letter appeared in the Irish Times (see Figure 6). Source: UK Met Office Daily Weather Reports.

Figure 4

$276 \times 129 \mathrm{~mm}(300 \times 300$ DPI) 
Figure 5 The poem 'Water' that appeared in The Weekly Irish Times on 30 December 1893. Italicised words identify those we had trouble transcribing due to blurring of the original.

Figure 5

$165 \times 153 \mathrm{~mm}(300 \times 300 \mathrm{DPI})$ 


\section{The Irish Times Sept. 16, 1893, page 6}

\section{The Protracted Drought}

TO THE EDITOR OF THE IRISH TIMES, Sir,- Adverting to the protracted drought, which is at present causing so much anxiety, I beg to offer a suggestion which I think would be worth trying. We all can perceive every evening the thick black masses of rain-cloud gathering over the city and suburbs, threatening to fall every instant, but still failing to come down. Now, I think this condition of the atmosphere would furnish a splendid opportunity for testing the power of dynamite as a rain producer. A few cartridges carried up by some paper balloons and exploded at a considerable altitude would, I think, be sufficient for the purpose. The experiment would prove novel and interesting, inexpensive, and would be a great treat to the citizens. Of course an open space, such as the Phoenix Park, would be the most suitable place for trying the experiment. Yours etc.,

\section{A. Citizen}

Figure 6 Letter to the Irish Times published 16 September 1893 proposing exploding dynamite over Dublin to induce rainfall.

Figure 6

$112 \times 159 \mathrm{~mm}(300 \times 300 \mathrm{DPI})$ 